\title{
Modelling of biomass temperature in the drying process
}

\author{
Ewa Golisz , Małgorzata Jaros, and Szymon Głowacki \\ Warsaw University of Life Sciences, Faculty of Production Engineering, Nowoursynowska 166, \\ 02-787 Warsaw, Poland
}

\begin{abstract}
The goal of the work was to propose and verify the model of temperature changes of the convective dried biomass depending on the drying time. The algebraic temperature model of the convective dried solid, giving the possibility of its direct calculation, was based on the logistic function of growth. Temperature model was verified for convective dried biomass: vegetable and wood (poplar and willow wood chips) significantly differing in initial moisture content. Parameter $\mathrm{W}$ in the temperature model, defined as the coefficient of temperature rate changes reaches greater values in higher temperature of drying air and for wood biomass which has lower initial moisture content. Empirically selected parameter $\mathrm{W}$ allows to verify the temperature model with the relative error less than $5 \%$.
\end{abstract}

\section{Introduction}

Biomass is third largest and most available natural source of energy, and is widely used in power industry [1-3]. Currently, the share of solid biomass in the RRE in Poland has increased from 88 to $92-94 \%$, and approx. $6 \%$ of biomass is used to produce biofuels. In Poland, $15 \%$ of energy is to be generated from RRE by 2020 , with biomass amounting to approx. 60\% [4].

Utilization of biomass for heat generation is conditioned by its low moisture. The drier the biomass, the higher its energy properties [5]. Biomass types suitable for energy purposes include wood biomass and plant-derived biomass that does not meet quality requirements for raw materials to be used as food or fodder, e.g. infected grain, fermenting or moulded pomace left over from the production of fruit or vegetable juices left for too long before processing, etc. In most cases, such biomass requires drying to obtain the desired combustion parameters and the required energy value of the fuel [6,7]. Due to the efficiency and technological availability, biomass is usually dried in forced convection, with wood being also dried in natural convection. Heat may efficiently be obtained from biomass when its moisture does not exceed $12 \%$. This parameter is also required for briquetting. Drying biomass under forced conditions is expensive. Therefore, predicting this process based on mathematical models of their computer simulations is recommended.

\footnotetext{
* Corresponding author: ewa_golisz@sggw.pl
} 
Principles of heat exchange in porous media have been known for a long time [8], as well as theoretical laws explaining the process of convection drying solids. From these laws follows a system of equations describing heat exchange and mass exchange [9], which is considered fundamental for mathematical modelling of convective drying of solid bodies:

$$
\begin{aligned}
& \frac{\partial t}{\partial \tau}=a \nabla^{2} \mathrm{t}+\varepsilon \frac{r}{c \rho} \frac{\partial u}{\partial \tau} \\
& \frac{\partial u}{\partial \tau}=a_{m}\left(\nabla^{2} u+\delta_{u} \nabla^{2} t\right)
\end{aligned}
$$

where:

$$
\begin{aligned}
& \mathrm{a} \text { - heat diffusion coefficient, } \mathrm{m}^{2} / \mathrm{s} \\
& \mathrm{a}_{\mathrm{m}}-\text { mass diffusion coefficient, } \mathrm{m}^{2} / \mathrm{s} \\
& \mathrm{c}-\text { specific heat of the moist body, } \mathrm{J} /(\mathrm{kgK}) \\
& \mathrm{r} \text { - water vaporization heat, } \mathrm{kJ} / \mathrm{kg} \\
& \mathrm{t} \text { - temperature of the body, }{ }^{\circ} \mathrm{C} \\
& \mathrm{u} \text { - moisture content, } \mathrm{kg} / \mathrm{kg} \\
& \varepsilon \text { - phase transition coefficient, }(-) \\
& \delta_{\mathrm{u}} \text { - thermal gradient coefficient, }(-) \\
& \rho \text { - density of the moist body mass, } \mathrm{kg} / \mathrm{m}^{3} \\
& \tau \text { - drying time, } \mathrm{s}
\end{aligned}
$$

The solution of this system of equations (1) requires the introduction of a series of simplifying assumptions. One of the most important of these assumptions is the assumption of the fact that the temperature of the material being dried remains constant and is equal to the temperature of the drying agent. As a result, a mathematical model of changes of water content in the material being dried is obtained. The solution in the form of infinite series is obtained for characteristic shapes of objects being dried, e.g. for a sphere:

$$
\frac{u(\tau)-u_{r}}{u(\tau=0)-u_{r}}=\frac{6}{\pi^{2}} \sum_{1}^{\infty} \frac{1}{n^{2}} \exp \left(-n^{2} \pi^{2} F o_{m}\right)
$$

where:

$\mathrm{u}_{\mathrm{r}}-$ equilibrium moisture content, $\mathrm{kg} / \mathrm{kg}$

$\mathrm{F}_{\mathrm{om}}-$ Fourier number for mass transfer, $(-)$

Practical application of this model requires further simplification to a simple exponential function, while determination of the temperature of the body being dried with simultaneous determination moisture content during drying, resulting from scientific knowledge laws, based on the solution of the system of equations (1), is possible only in the numeric form, e.g. $[10,11]$. Such a model has limited practical application, due to the fact that it does not have the algebraic form, and as such, it cannot be used for steering and control of the process of drying.

The goal of the work was to propose and verify the model of temperature changes from time drying. The model verified for woody biomass and vegetable biomass, significantly differing in initial moisture content, is a generalized model for objects with significantly different moisture. The algebraic temperature model of the convective dried solid, giving the possibility of its direct calculation, was based on the logistic function of growth [12].This function is used to describe many economic, social, natural and other phenomena [13]. In the work, the parameters of the models were sought in order to use the model both in the period, in which external conditions of heat and mass transfer determine drying, and in the period, in which internal diffusion dominates. 


\section{Modelling of temperature}

Assumptions simplifying the solution of the equations (1) related to the temperature of the body being dried, in the period, in which external conditions of transfer dominate, $t=t_{M}$, (the so called 1st stage of drying) and in the period, in which transfer resulting from internal diffusion dominates, $\mathrm{t}=\mathrm{t}_{\mathrm{p}}$ (2nd stage) result from the assumptions of mathematical theory of convective drying of solid bodies [14]. Such a simplifying assumption is practically justified in case of grain and seeds which are small, have relatively low moisture content and become dry in the second stage of drying because the time in which they reach the temperature of the drying agent is insignificant compared with the amount of time required to reach the content of water desired from the technological point of view [15]. In case of bodies with the moisture ranging from 30 to $50 \%$ (e.g. wood biomass) and bodies with high moisture content that initially dry in the first and then in the second period of drying, e.g. fruit-vegetable biomass, with the moisture content higher than $50 \%$ (e.g. pomace left over from juice production) that take a long time to heat to the temperature of the drying agent due to their material structure, such an assumption is a large simplification of the characteristic of continuous change of the temperature of the material being dried.

Figures 1 and 2 show example results of vegetable and wood biomass temperature measurements for a few temperatures of drying air. In the process of drying vegetable biomass, four periods of increase of the temperature of its particles may be indicated, which differ in dynamics and duration. The four periods are: the period of initial heating - a short period compared to the total drying time, and which may be disregarded; the second period, in which the temperature of the surface of the particles being dried is rising slowly within the range of wet thermometer for given drying conditions; the third period when the temperature rises quickly and the last period, in which the temperature of the biomass slowly approaches the temperature of the drying air. Apart from initial heating, durations of the other periods may not be considered insignificant. Such a situation characterizes sizereduced plant biomass with large initial moisture content - higher than $1 \mathrm{~kg}_{\mathrm{H} 2 \mathrm{O}} / \mathrm{kg}_{\mathrm{dm}}$ (relative moisture higher than 50\%). Therefore, it was necessary to formulate a mathematical model of temperature describing its continuous (and not discrete) increase from the value of the temperature of wet thermometer to the temperature of the drying air.

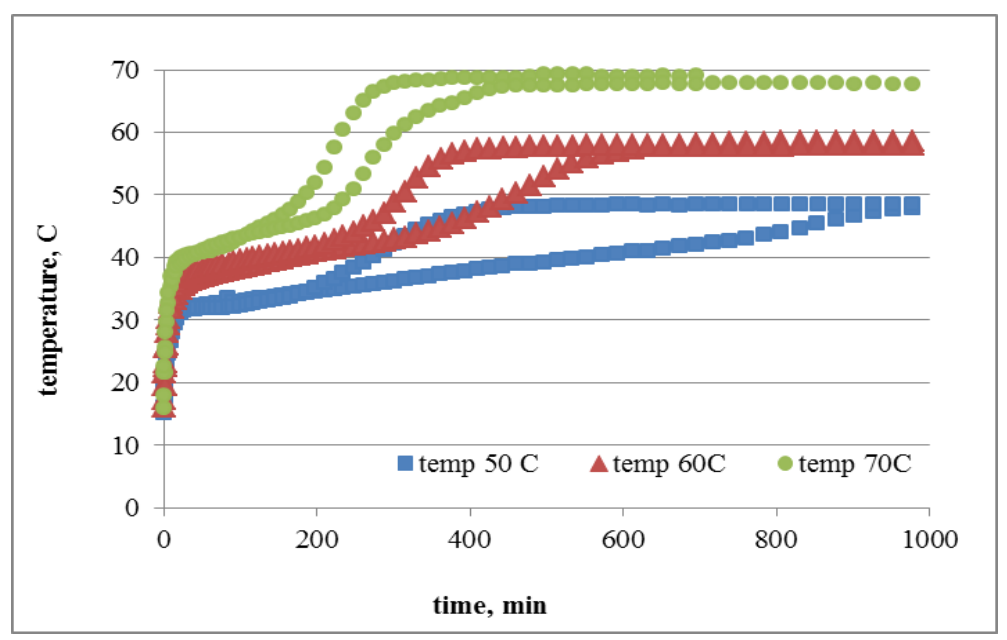

Fig 1. Measurements of temperature of vegetable biomass particles - vegetable marc, dried at drying air temperatures of $50^{\circ}, 60^{\circ}$ and $70^{\circ} \mathrm{C}$ 
In case of biomass with lower initial moisture content, e.g. wood biomass, the surface of particles is dry enough for the drying air with the temperature higher than the temperature of biomass to heat it quickly and maintain thermal balance determined by the temperature close to the temperature of the drying air.

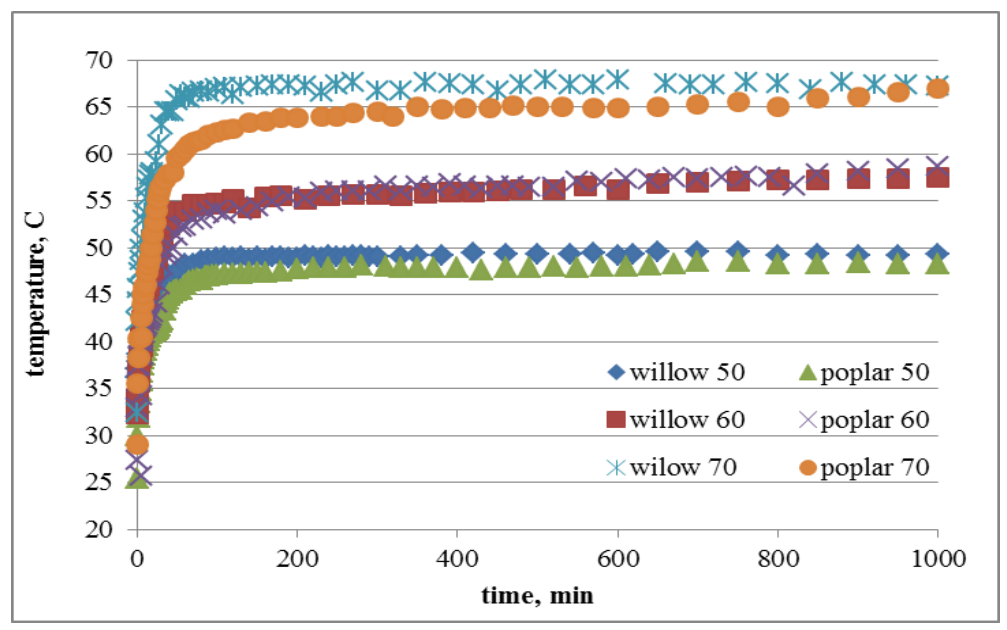

Fig 2. Measurements of temperature of wood biomass particles dried at drying air temperatures of $50^{\circ}, 60^{\circ}$ and $70^{\circ} \mathrm{C}$

The research goal of this work was to verify whether the change of the temperature of both types of biomass may be described by a mathematical model based on logistic function.

\subsection{A logistic model of the increase of the temperature of the solid body in the process of drying}

There is an analogy between the increase of the temperature of a solid body being convective dried by heated air and the increase of the dependent variable in the logistic function, which models changes of a certain quantity $\mathrm{y}(\mathrm{x})$, from $\mathrm{y}_{0}$ to $\mathrm{y}_{\mathrm{k}}$, with the coefficient $A$ being the increase rate. It is the solution of the differential equation with split variables, also called Robertson's equation, which may be presented in the following way:

$$
\frac{d y}{d \tau}=A y\left(y_{\max }-y\right)
$$

The solution with the initial condition $\mathrm{y}(\mathrm{x}=0)=\mathrm{y}_{0}$, has the following form:

$$
y(x)=\frac{y_{0} y_{\max }}{y_{0}+\left(y_{\max }-y_{0}\right) \exp \left(-A x y_{\max }\right)}
$$

It is worth noting that the rate of changes $\mathrm{dy} / \mathrm{dx}$ is parabolic relative $y$, and the boundary values of this logistic function are: $\lim _{x \rightarrow-\infty} y(x)=0$ and $\lim _{x \rightarrow+\infty} y(x)=y_{\max }$. The usefulness of the above logistic function for the description of the increase of the temperature of moist biomass dried by convection was considered, assuming structural analogy of different growth processes. However, it required modification of formula (3) so that: $\lim _{x \rightarrow-\infty} y(x)=y_{\min }>0$, and $\mathrm{y}_{0}=\mathrm{y}_{\min }+\mathrm{e}$, where $e$ denotes selected parameter of translation of the function graph (3), allowing to obtain small increments $y(x)$ but within the range of increasing rate of changes $\mathrm{dy} / \mathrm{dx}$. 
The logistic model of heating of moist particles of biomass dried by heated air was formulated in a similar way as for vegetables during drying $[16,17]$.

The lowest temperature included in the presented model is the temperature of wet thermometer $t_{M}$, then the temperature of the body being dried $t(\tau)$ changes from $t_{0}=t_{M}+e$ to $\mathrm{t}_{\max }=\mathrm{t}_{\mathrm{p}}$ where $e$ is the value resulting from measurement uncertainty, selected empirically. In connection with this, the following hypothesis was assumed: the rate of changes of the average temperature of the solid body being dried is proportional to the product of difference: between the temperature $t_{\mathrm{p}}$ of the drying agent and the average temperature $t$ of the body as well as the temperature $t$ of the body and the temperature of wet thermometer $t_{M}$ and to a certain coefficient $W$, which depends on the conditions of external exchange (e.g. on the conditions of heat penetration, exchange area), which may be written as follows:

$$
\frac{d t}{d \tau}=W\left(t_{p}-t\right)\left(t-t_{M}\right)
$$

Then the model of the temperature has the following form:

$$
t(\tau)=t_{M}+\frac{\left(t_{0}-t_{M}\right)\left(t_{p}-t_{M}\right)}{\left(t_{0}-t_{M}\right)+\left(t_{p}-t_{0}\right) e^{-W\left(t_{p}-t_{M}\right) \tau}}
$$

Figure 3 presents graphs of temperatures calculated from formula (5) for $t_{p}=60^{\circ} \mathrm{C}, t_{0}=25^{\circ} \mathrm{C}$ and for different coefficients $W$.

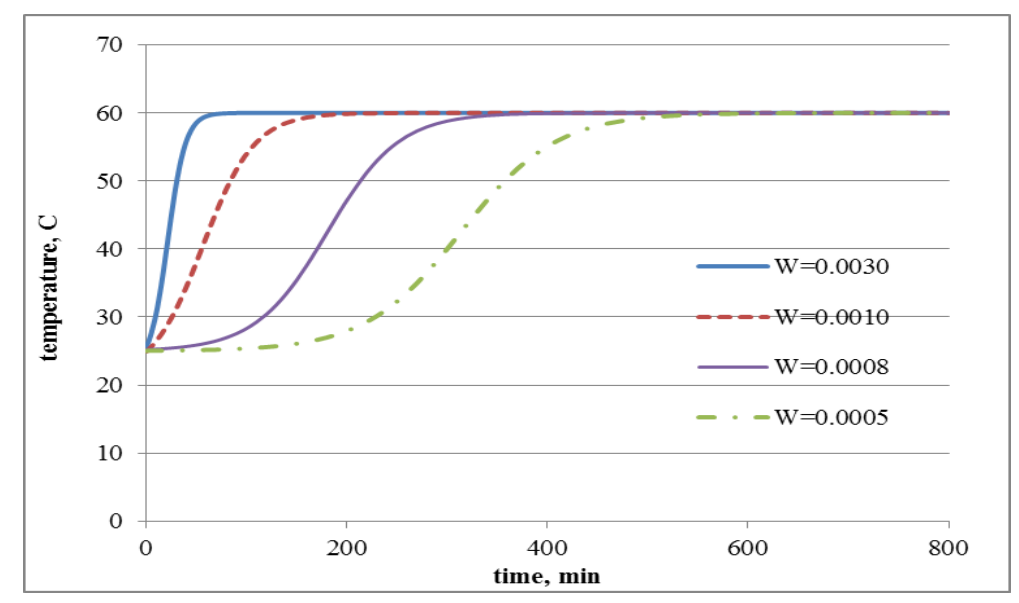

Fig. 3. Graphs of the logistic function (4) simulating the increase of the temperature in time, from $25^{\circ} \mathrm{C}$ to $60^{\circ} \mathrm{C}$, for three example values of the coefficient $\mathrm{W}$ of growth rate

As it may be observed, the graphs of the logistic function for smaller values of coefficient $\mathrm{W}$, equal to 0.0005 and 0.0008 are similar to graphs of changes of the temperature of vegetable biomass, which is characterized by high initial moisture content. However, the model of logistic curve, in which the coefficient of temperature change rate $\mathrm{W}=0.0010$ and 0.0030 may describe changes of temperature in the process of wood biomass drying.

It is worth presenting the structure of the model of temperature (5) in another form due to its clarity, introducing the following denotations:

$$
\left.a=\frac{t_{p}-t_{0}}{\left(t_{p}-t_{M}\right)\left(t_{0}-t_{M}\right.}\right) \quad b=\frac{1}{\left(t_{p}-t_{M}\right)}, \quad m=-W\left(t_{p}-t_{M}\right) .
$$


And, finally we obtain:

$$
t(\tau)=t_{M}+\frac{1}{a \cdot \exp (m \tau)+b}
$$

Equations (5) and (7) are semi-empirical models because they were theoretically introduced as a consequence of the proposed hypothesis, by similarity of the logistic function. The models allow for calculating values of changes of the temperature of the dried body, similar to those based on measurements, only disregarding the initial period of heating.

\section{Results and discussion}

Figures 4-6 present graphs/plots of changes of the temperature of convective dried biomass, obtained from measurements and calculated from model (7).

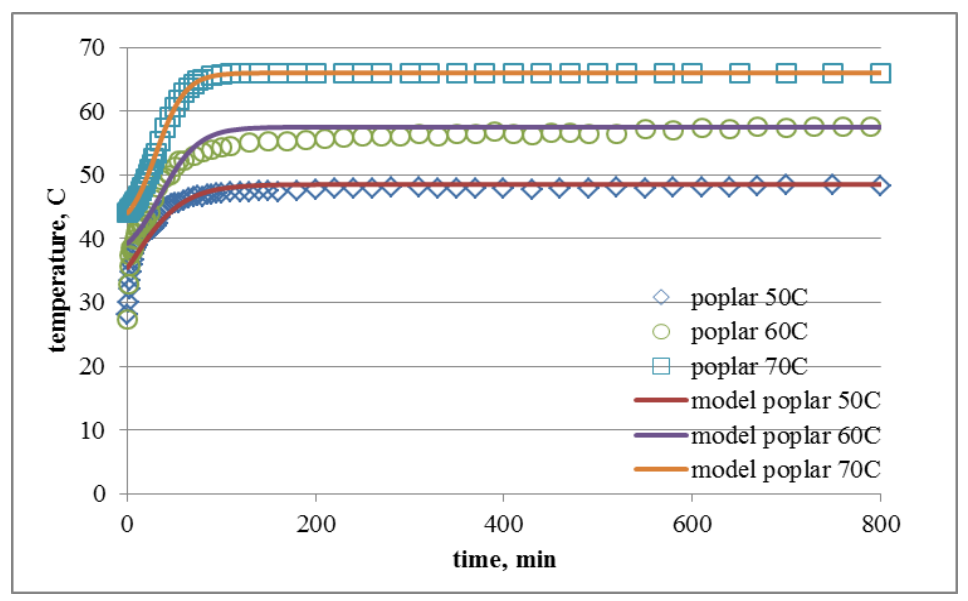

Fig. 4 Results of measurements and calculations of the temperature of poplar chips dried at air temperatures of $50^{\circ}, 60^{\circ}, 70^{\circ} \mathrm{C}$ using logistic function (7)

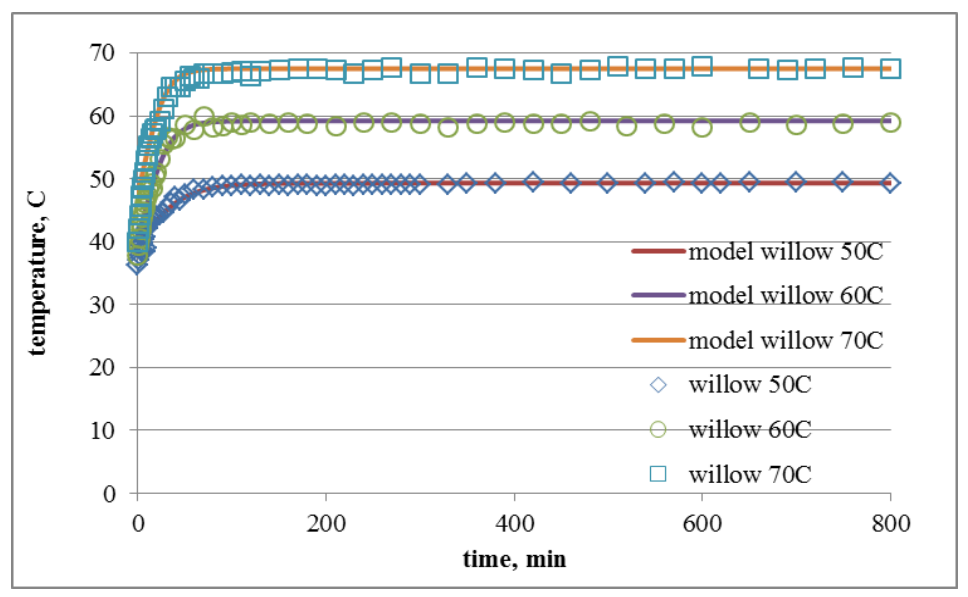

Fig. 5 Results of measurements and calculations of the temperature of willow chips dried at air temperatures of $50^{\circ}, 60^{\circ}, 70^{\circ} \mathrm{C}$ using logistic function (7) 


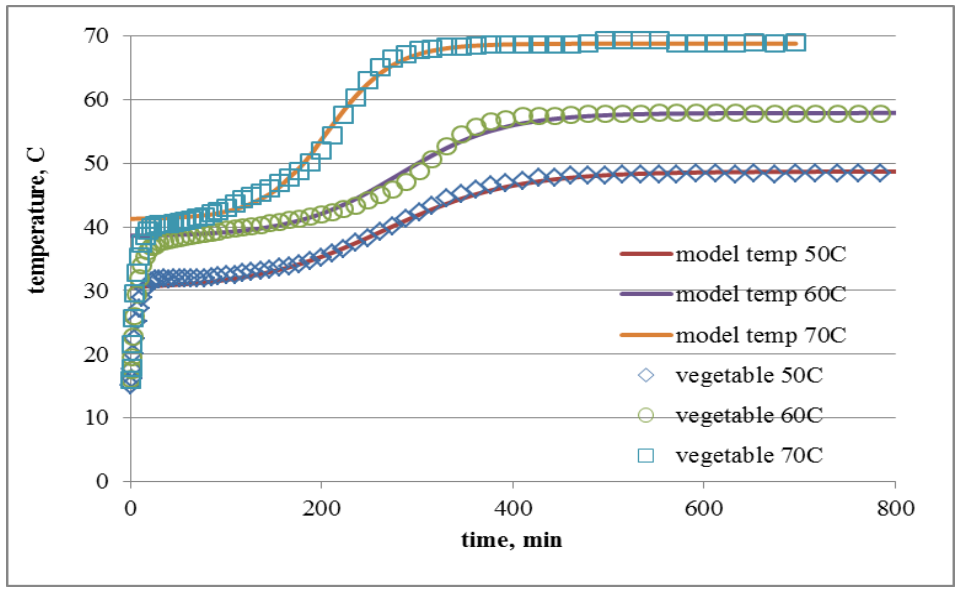

Fig. 6 Results of measurements and calculations of the temperature of vegetable biomass dried at air temperatures of $50^{\circ}, 60^{\circ}, 70^{\circ} \mathrm{C}$ using logistic function (7)

As the graphs show, model (7) approximates the results of temperature measurements well. Identification of the parameters of the model (7), involving selection of coefficient W and temperature $t 0$, enabled empirical verification of the model with a maximum relative error of the model smaller than $5 \%$.

Table 1 presents values of coefficient of temperature change rate $\mathrm{W}$ for logistic function approximating changes of temperature of biomass particles being dried for 3 temperatures of drying air.

Table 1. Values of coefficient $\mathrm{W}$ for different types of biomass

\begin{tabular}{|c|c|c|c|}
\hline $\mathrm{t}_{\mathrm{p}}\left[{ }^{\circ} \mathrm{C}\right]$ & \multicolumn{3}{|c|}{$\mathrm{W}\left[{ }^{\circ} \mathrm{C}\right.$ min-1] } \\
\hline & poplar & willow & vegetables \\
\hline 50 & 0.00160 & 0.00160 & 0.00080 \\
\hline 60 & 0.00230 & 0.00220 & 0.00095 \\
\hline 70 & 0.00260 & 0.00250 & 0.00105 \\
\hline
\end{tabular}

Practice indicates that in higher temperatures moist solids become heated and dry faster. The fact was also confirmed by the presented model of the temperature. Coefficient of temperature increase rate $\mathrm{W}$ assumes higher values for higher drying temperatures. For drying air temperature of $50^{\circ} \mathrm{C}$ it was equal from 0.0008 to 0.00160 . Wood biomass, which has lower initial moisture content, becomes heated much faster, and it is also reflected in the model as coefficient $\mathrm{W}$ for wood biomass is approx. 2-2.5-fold greater than for vegetable biomass.

\section{Conclusions}

Model of changes of the temperature of a convective-dried solid body, based on a logistic growth function, was empirically confirmed for wood biomass and vegetable biomass. Parameter $\mathrm{W}$ in the temperature model, defined as the coefficient of temperature rate changes, has numerical values logically justified in the presented research by the properties of the biomass being examined, reaches greater values in higher temperature of drying air. Empirically selected parameter $\mathrm{W}$ allows to verify the temperature model with the relative error, which does not exceed 5\%. 
Model of the temperature of heating of solid body being dried may be used for controlling drying air temperature, and thus increasing the efficiency of convective drying. Temperature model (7) may also be used to formulate theoretical model of changes of moisture content not only in the numerical form but also in the algebraic form.

\section{References}

1. P.I. Boerjesson, Energy analysis of biomass production and transportation. Biomass Bioenergy. Vol. 11 pp. 305-318, (1996)

2. Dunnett, N. Shah, Prospects for Bioenergy. Journal of Biobased Materials and Bioenergy. Vol. 1 pp. 1-18 (2007)

3. A. Roszkowski, Bioenergia - pola i lasy zastąpią węgiel, ropę i gaz? Inżynieria Rolnicza. Nr 1 pp. 243-257, (2009)

4. A Roszkowski, Biomasa i bioenergia - bariery technologiczne i energetyczne. Problemy Inżynierii Rolniczej. PIR (VII-IX): z. 3 (77) s. 79-100, (2012)

5. W. Lewandowski, M. Ryms, Biopaliwa. Proekologiczne odnawialne źródła energii, WNT Warszawa, pp. 22 - 26, (2013)

6. Grzybek, Kierunki zagospodarowania biomasy na cele energetyczne. Wieś Jutra, 9(62), pp. 10-11 (2003)

7. Kościk, Rośliny energetyczne. Wyd. AR Lublin (2003)

8. M. Kawiany, Principles of heat transfer in porous media. Springer, pp. 153-232 (2002)

9. W Łykow, J. A Michaiłow, Tieoria tiepło i massoperenosa, Gos. Energ., Moskwa, (1963)

10. R.M. Abalone, A. Lara, R. Gaspar, R.D. Piacentini, Drying of biological products with significant volume variation. Experimental and modeling results for potato drying. Drying technology. Volume 12, (1994)

11. J.C., Laquerre, A. Lebert, G. Trystram, J.J. Bimbebet, A compartmental model to describe drying curves of foodstuffs under variable conditions. Drying'91 edited by A.S. Mujumbdar and Filikova, Elsevier Sciencw Publishers, Amsterdam (1991)

12. M. Jaros, Kinetyka suszenia warzyw, Rozprawa habilitacyjna (1999)

13. H. Spustek, Modele interdyscyplinarne w nauce.[w]: Historia testis temporum, lux veritatis, vita memoriae, nuntia vetustatis. Księga Jubileuszowa dedykowana Profesorowi Włodzimierzowi Kaczorowskiemu]. Wydawnictwo Uniwersytetu Opolskiego, s.755-768 (2015)

14. S. Pabis, Teoria konwekcyjnego suszenia produktów rolniczych. PIWRiL, Warszawa (1982)

15. S. Pabis, S.M. Henderson, Grain drying theory, III: The air grain temperature relationship. J. Agric. Engng Res, 7 pp.21-26,(1962)

16. M. Jaros Modelowanie temperatury warzyw suszonych konwekcyjnie, [w] Konwekcyjne suszenie warzyw. Teoria i praktyka. (praca zbiorowa pod red. S. Pabisa), PTIR, Warszawa, (1999)

17. E. Golisz, M. Jaros, Probabilistyczny model temperatury konwekcyjnie suszonej krajanki pora. Inżynieria Rolnicza 5(38)/2002, pp.393-398 (2002) 